\title{
Penile Cancer cN2 TNM Finding v8
}

National Cancer Institute

\section{Source}

National Cancer Institute. Penile Cancer cN2 TNM Finding v8. NCI Thesaurus. Code C140053.

Penile cancer with palpable mobile two or more unilateral inguinal nodes or bilateral inguinal lymph nodes. (from AJCC 8th Ed.) 